\title{
Directional Confinement Effect of Geogrid on Deformation and Bearing Capacity of Reinforced Sand under Cyclic and Monotonic Loadings
}

\author{
AUNG AUNG SOE${ }^{1}$, Jiro KUWANO², Shinya TACHIBANA ${ }^{3}$ and Ilyas AKRAM ${ }^{4}$ \\ Deformation behavior and bearing capacity of geogrid-reinforced sand were investigated through experimental \\ study. Series of cyclic and monotonic loading tests were performed by using a large container, a rectangular footing \\ and two geogrid types: triangular and biaxial. Footing orientation was considered as a parameter to examine the \\ directional confinement effect of the geogrid. Test results showed that this effect was obvious on the development of \\ permanent deformation and on the ultimate bearing capacity of reinforced sand. However, this influence became \\ smaller on the ultimate bearing capacity if a stiffer geogrid was used for reinforcement. Significant reduction in \\ permanent deformation and beneficial improvement in bearing capacity were observed in all geogrid-reinforced tests.
}

KEYWORDS: Reinforced Sand, Cyclic Loading, Permanent Deformation, Bearing Capacity

\section{Introduction}

Behavior of reinforced soil foundation has been studied by many researchers over decades. In those studies, different types of material were used for reinforcement such as metal strips, coir, and other materials. Later, geosynthetic materials were introduced in the geotechnical engineering and became popular in various earth structures, due to their beneficial improvements.

Depending on the type and purpose of applications, there are different geosynthetic materials, e.g. geotextile, geomembrane, geocell and geogrid. Among them, geogrid has been successfully utilized for reinforcing purposes. Generally, geogrid can be distinguished into three types: uniaxial, biaxial and triangular geogrids (also called multiaxial geogrid). Biaxial geogrid and triangular geogrid were used in the present study.

Although different studies had been conducted by many researchers, such as Yetimoglu et al. ${ }^{1)}$, Adams \& Collin ${ }^{2)}$, Murad et al. ${ }^{3)}$, Ashmawy \& Bourdeau ${ }^{4)}$ and Shin \& Das $^{5)}$, behavior of geogrid-reinforced soil is still necessary to understand because of its complex reinforcement mechanisms. A. K. Ashmawy and P.L. Bourdeau $^{4)}$ reported that the interaction mechanism is affected by several factors including state of stress within reinforced soil mass; nature of loading; reinforcement direction; boundary conditions; and material and interface properties. Several studies were conducted by many researchers to characterize the reinforcement mechanisms of geogrid. In this study, the reinforcement direction of geogrid will be investigated by considering the rectangular footing orientation so that it will be possible to quantify the directional confinement effect on the deformation and bearing capacity of reinforced sand.

To investigate the directional confinement effect, series of cyclic loading tests have been performed under different footing orientations. A slender rectangular footing was used as the model foundation, and its orientation was considered as a parameter. Hence, lateral confinement effect will be known with respect to each footing orientation. After cyclic loading, the subsequent monotonic loading tests were performed to estimate the ultimate bearing capacities of geogrid-reinforced sand. Then, these values were compared with the ultimate bearing capacities obtained from the pure monotonic loading tests.

\section{Experimental program}

In this program, seven cyclic plate loading tests with six subsequent monotonic loading tests and three pure monotonic loading tests were performed to study the deformation behavior of geogrid-reinforced sand and ultimate bearing capacity. Rectangular footing orientations were specified as 0,45 and 90-degrees with respect to the geogrid layout. For no reinforcement case, cyclic loading test and monotonic loading test were separately performed with 0-degree footing orientation. Similarly, pure monotonic loading tests for geogridreinforced sand were also carried out with 0 -degree footing orientation.

\footnotetext{
${ }^{1}$ Student Member of JGS, Graduate Student, Graduate School of Science and Engineering, Saitama University.

${ }^{2}$ International Member, Graduate School of Science and Engineering, Saitama University.

${ }^{3}$ International Member, Research Center for Urban Safety and Security, Kobe University.

${ }^{4}$ Student Member of JGS, Graduate Student, Graduate School of Science and Engineering, Saitama University.
} 


\section{Materials}

\subsection{Silica sand}

Nikko Silica Sand No.5 was used for model soil sample preparation. This sand has a particle density of $2.675 \mathrm{~g} / \mathrm{cm}^{3}$. The average soil particle size, $\mathrm{D}_{50}$, is 0.488 $\mathrm{mm}$. Since uniformity coefficient, $\mathrm{C}_{\mathrm{u}}=1.98$, and curvature coefficient, $\mathrm{C}_{\mathrm{c}}=0.943$, are not in specified range, this sand can be regarded as poorly graded sand, $\mathrm{SP}$, according to the unified soil classification system $(\mathrm{USCS})^{6)}$. The grain size distribution curve is shown in Figure 1. The maximum and minimum dry densities are $1.628 \mathrm{~g} / \mathrm{cm}^{3}$ and $1.338 \mathrm{~g} / \mathrm{cm}^{3}$. The corresponding minimum and maximum void ratios are 0.643 and 1.0. Direct shear tests were also carried out to determine the internal friction angle of this sand. This angle was $33.5^{\circ}$, corresponding to the average relative density, $\mathrm{D}_{\mathrm{r}}$, of 70 $\%$, which was used in all test cases.

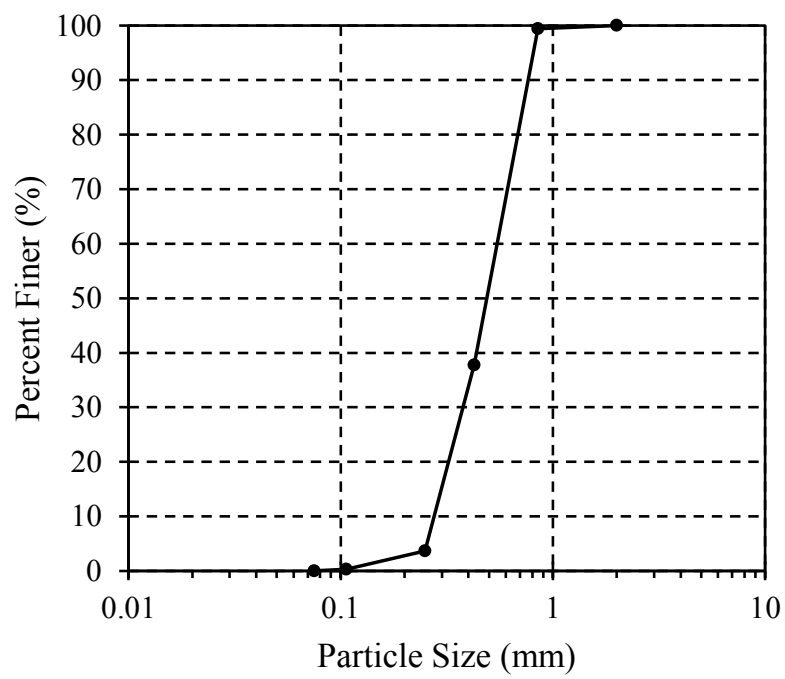

Figure 1. Grain size distribution curve of Nikko Silica Sand No.5

\subsection{Geogrid}

Two types of geogrids were used to investigate the deformation behavior and bearing capacity characteristics of reinforced sand. They are triangular geogrid, TX160, and biaxial geogrid, SS35, which are products of Tensar. These geogrids are made of punched polypropylene sheets. Product specifications of geogrids, provided by manufacturer, are presented in Table 1 . Triangular geogrid has the same tensile strengths of 10 $\mathrm{kN} / \mathrm{m}$ in the diagonal direction, $\mathrm{X}$, and cross machine direction, C. On the other hand, biaxial geogrid has different tensile strengths; $34 \mathrm{kN} / \mathrm{m}$ in machine direction, $\mathrm{M}$, and $43 \mathrm{kN} / \mathrm{m}$ in cross machine direction, $\mathrm{C}$. The schematic diagrams of triangular geogrid and biaxial geogrid are illustrated in Figure 2.
Table 1. Product specifications of geogrids

\begin{tabular}{|c|c|c|c|c|}
\hline \multirow{2}{*}{ Geogrid } & \multicolumn{2}{|c|}{ TX160 } & \multicolumn{2}{|c|}{ SS35 } \\
\hline & $X^{*}$ & $\mathrm{C}^{*}$ & $M^{*}$ & $\mathrm{C}^{*}$ \\
\hline Tensile strength, $\mathrm{kN} / \mathrm{m}$ & \multicolumn{2}{|c|}{10} & 34 & 43 \\
\hline Rib thickness, mm & 1.6 & 1.4 & 3.1 & 1.8 \\
\hline Junction thickness, mm & \multicolumn{2}{|c|}{3.1} & \multicolumn{2}{|c|}{4.2} \\
\hline Unit weight, $\mathrm{g} / \mathrm{m}^{2}$ & \multicolumn{2}{|c|}{245} & \multicolumn{2}{|c|}{620} \\
\hline
\end{tabular}

*Direction: $\mathrm{X}=$ diagonal; $\mathrm{C}=$ cross machine; $\mathrm{M}=$ machine

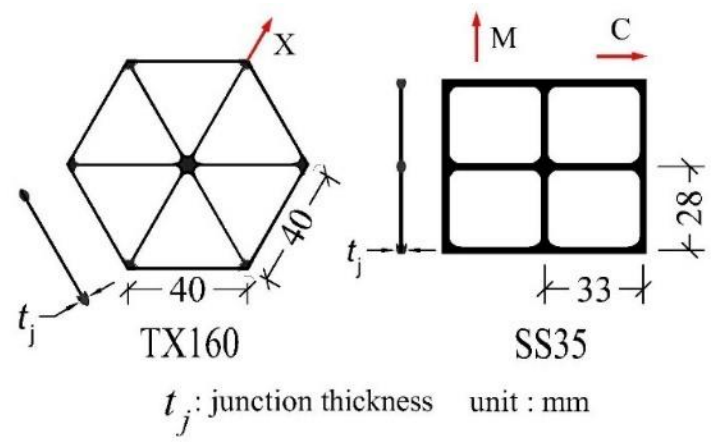

Figure 2. Schematic diagram of geogrids

\section{Experimental setup and testing procedure}

Large container: $100 \mathrm{~cm}$ in length, $100 \mathrm{~cm}$ in width and $80 \mathrm{~cm}$ in depth, was used for model ground preparation. Rigid rectangular steel plate, length: $\mathrm{L}=27.5 \mathrm{~cm}$ and width: $\mathrm{B}=8.75 \mathrm{~cm}$, was used as a model footing. Since the depth of soil mass was about $70 \mathrm{~cm}$ in each test, the influence of applied footing pressure would be negligible for this depth according to Boussinesq stress distribution analysis ${ }^{7)}$. In addition, the minimal interference of side wall would be expected since the ratio between container size and footing width was large enough ${ }^{1)}$ ), $100 / 8.75=$ 11.43 .

Model ground was uniformly prepared by using $100 \mathrm{~kg}$ of sand for each lift. The average density was $1.53 \mathrm{~g} / \mathrm{cm}^{3}$, $\mathrm{D}_{\mathrm{r}}=70 \%$. In reinforced sand tests, geogrid was laid at $2.6 \mathrm{~cm}$ depth $(=\mathrm{u})$, resulting depth of geogrid layer to footing width ratio, $\mathrm{u} / \mathrm{B}$, equals 0.3 , which can be regarded as an optimum value according to Yetimoglu et al. ${ }^{1)}$; Murad et al. ${ }^{3)}$, Gabr \& Hart $^{9)}$ and Das ${ }^{10)}$. Experimental layout and loading sequences are shown in Figure 3.

Footing was set at the center with loading system, which was operated by pneumatic actuator. As shown in Figure 3, cyclic load was first applied at the rate of one cycle per minute, with a maximum amplitude of $2.4 \mathrm{kN}$, corresponding to $100 \mathrm{kPa}$. In case of no reinforcement, one cyclic loading test was performed with one footing orientation which was taken as 0-degree footing orientation. For geogrid-reinforced sand cases, three footing orientations were taken as 0,45 and 90-degrees, as illustrated in Figure 4. 


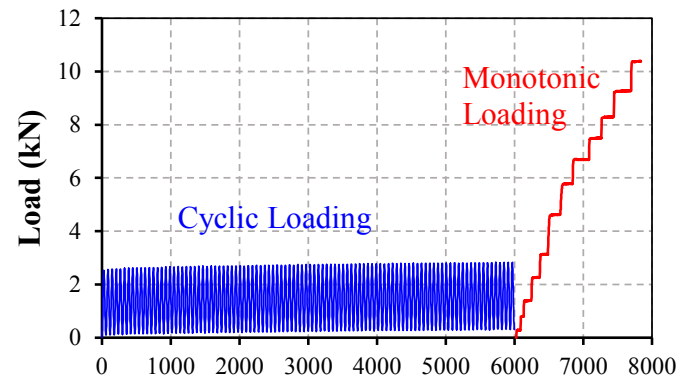

Time (sec)

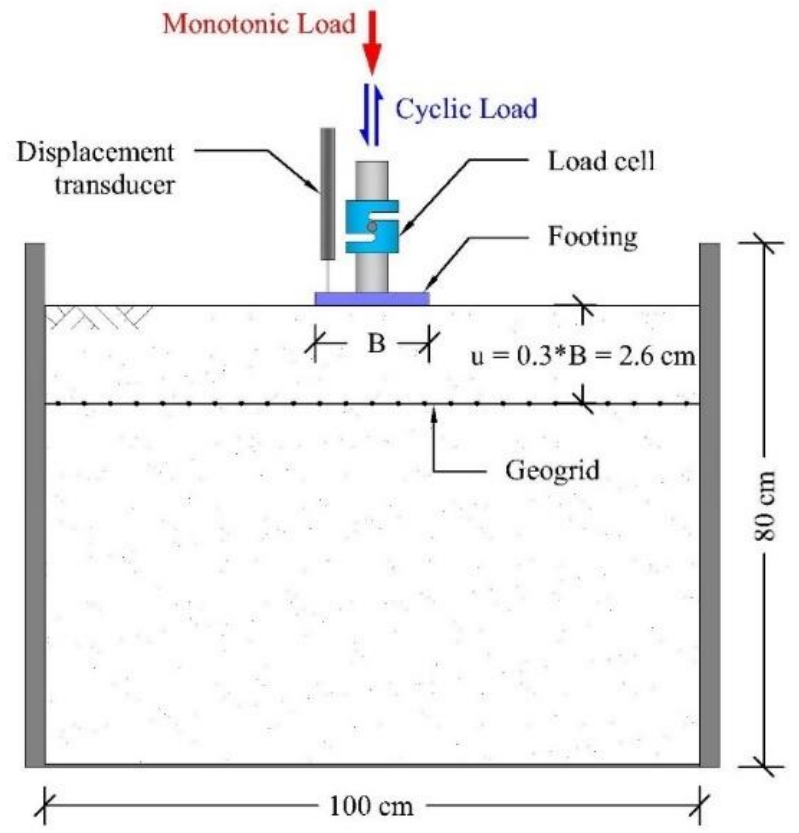

Figure 3. Experimental layout and loading sequences

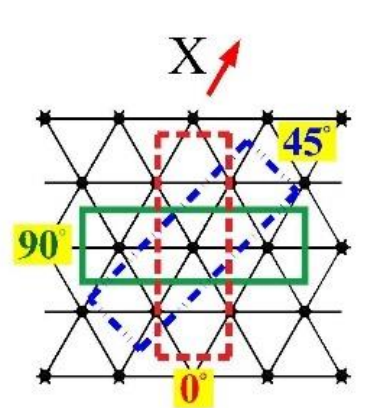

TX160

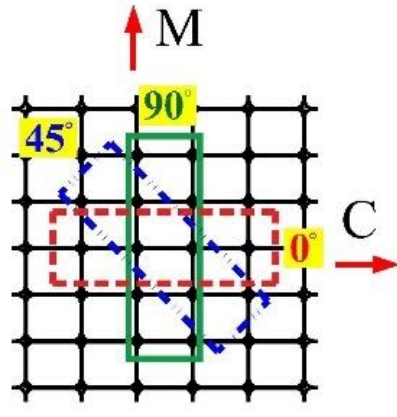

SS35
*Dircction: $\mathrm{X}=$ diagonal; $\mathrm{C}=$ cross machine; $\mathrm{M}=$ machine

Figure 4. Relative positions between geogrid and footing orientations

After cyclic load had been allowed to apply 100 times, monotonic load was subsequently applied. Each monotonic loading step was maintained until the rate of footing settlement was less than $0.02 \mathrm{~mm}$ per minute. The same loading manner was followed in pure monotonic loading tests, in which 0 -degree footing orientation was taken as a reference. During each experiment, a linear variable displacement transducer was set on the footing to measure the footing settlement, and load variation was monitored by a load cell. Data were recorded at every 2 second by data acquisition system.

\section{Results and discussion}

\subsection{Permanent deformation under cyclic loading}

Seven cyclic loading tests were performed with no reinforcement, triangular geogrid reinforcement and biaxial geogrid reinforcement. From the test results, permanent deformation in each load cycle was taken when the load was minimum. Then, this deformation was normalized by the footing width, and it is presented as the percent settlement ratio, s/B in the Figures 5, 6 and 7. For no reinforcement case, the variation of this ratio with the number of load cycles is shown in Figure 5.

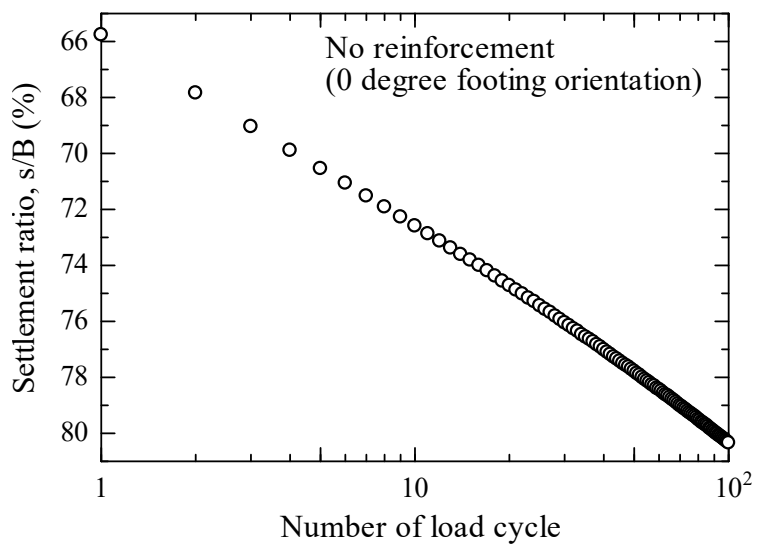

Figure 5. Load cycle vs. s/B ratio for no reinforcement

From the Figure 5, it was noticed that the settlement ratio increased linearly with the logarithmic scale of load cycles, from $66-80 \%$. This large deformation in no reinforcement case implies that soil has already been failed within first cycle of loading. In addition, the increasing tendency of settlement ratio was observed till the end of cyclic loading.

In a reinforced soil mass, three mechanisms can develop under monotonic and cyclic loading ${ }^{4}$. According to Anderson, R. P. ${ }^{11)}$, lateral restraint or confinement is the primary reinforcement mechanism of geogrid. In this study, rectangular footing orientation was taken into account in order that the lateral confinement effect of each geogrid type could be realized with respect to each direction. The variations of settlement ratio, s/B, for triangular geogrid-reinforced sand are presented in Figure 6.

In Figure 6, it was observed that the initial settlement ratios were almost same, $7-8 \%$, for all footing orientations. However, for 0 -degree footing orientation, 
this settlement ratio increased more rapidly than other footing orientation cases. This could be the fact that the confinement effect was less in this given footing configuration to the geogrid layout. As shown in Figure 4 , there is no parallel rib along the length of footing in 0 degree footing orientation. In addition, the angle formed between diagonal ribs are relatively wide to the lateral direction of this footing configuration. Therefore, lateral confinement effect might be smaller in this footing orientation, compared to other orientations. As a result, larger settlement ratios were noticed with increasing load cycles.

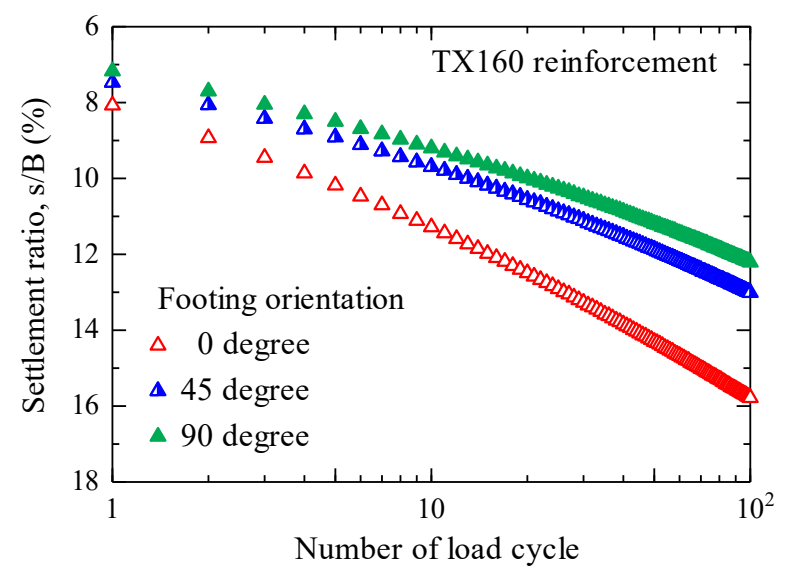

Figure 6. Load cycle vs. s/B ratio for triangular geogrid reinforcement

For other footing orientations, 90-degree case showed a slightly smaller $\mathrm{s} / \mathrm{B}$ ratio than 45 degree case for the given load cycle. This better improvement might have been contributed from the better confinement effect of the triangular geogrid in this footing orientation. As seen in Figure 4, there are parallel tensile ribs along the length of footing and diagonal ribs, forming narrow angle to the lateral direction of 90 degree footing orientation. Therefore, these tensile ribs combination would contribute to more confinement and result in the reduction of permanent deformation of reinforced sand. From the test data, it was observed that permanent deformation developed under cyclic loading was significantly reduced with the inclusion of triangular geogrid reinforcement, ranging from 80 to $85 \%$ after 100 cycles of loading.

The behavior of settlement ratios for biaxial geogrid reinforcement is shown in Figure 7. Although the initial settlement ratios were almost same for 0 and 90 footing orientations, this ratio for 45-degree footing orientation was considerably small, and showed the lowest values with the number of load cycles. This better performance was appeared from the higher confinement effect in 45 degree footing orientation, though there was no parallel tensile ribs along the length of footing. This could be the result of mutual confinement effect from two perpendicular ribs, which form a narrow angle to the transverse direction of 45-degree footing orientation.
Hence, it was realized that the confinement effect will be larger with smaller angle of ribs, formed in the lateral direction of rectangular footing.

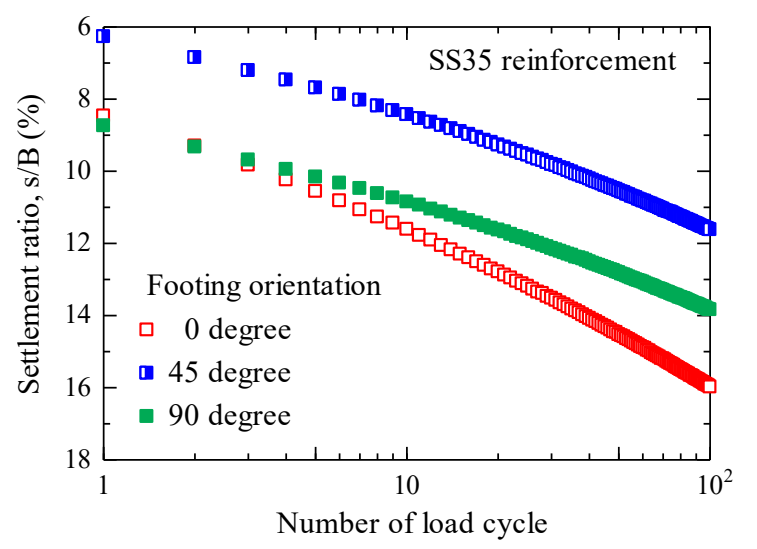

Figure 7. Load cycle vs. s/B ratio for biaxial geogrid reinforcement

For 0 and 90 footing orientations, despite almost same initial settlement ratios, the difference between two cases became more obvious with increasing number of load cycles. This could be the influence of rib thickness. From the information presented in Table 1, rib thickness in machine direction, $M$, of biaxial geogrid is larger than that in cross machine direction, C. Furthermore, this machine direction is parallel to the 90-degree footing orientation, as shown in Figure 4. With the difference in rib thicknesses of biaxial geogrid, this influence became more obvious with load cycles on the permanent deformation behavior in the cyclic loading test.

In all biaxial geogrid reinforcement cases, the development of permanent deformations could have been reduced from 80 to $86 \%$ after 100 cycles of loading. Therefore, the overall performances for both types of geogrid are equivalent to each other under the cyclic load of $100 \mathrm{kPa}$ maximum pressure. However, the deviation of $\mathrm{s} / \mathrm{B}$ ratios with footing orientations is larger in biaxial geogrid reinforcement than in triangular geogrid reinforcement. Interestingly, in all cases, including no reinforcement and geogrid reinforcements, the increasing tendencies of $\mathrm{s} / \mathrm{B}$ ratio were observed with increased in load cycles. Shin and Das ${ }^{5)}$ reported that this ratio became apparently constant between $1.75 \times 10^{5}$ and $2.5 \times 10^{5}$ cycles for reinforced soil, and $1.5 \times 10^{5}$ and $2.0 \times 10^{5}$ cycles for unreinforced soil. Unfortunately, in this study, the number of load cycles could not reached to this level due to the limitations of test condition. Since the increasing tendencies of settlement ratios vary with respect to the footing orientations, the directional confinement effect of a geogrid might affect the long term performance of the reinforced earth structure.

\subsection{Rebound percentage under cyclic loading}

The percentage of rebound was calculated by using the footing settlement values at the lowest and the highest 
pressures in each cycle of loading. The settlement at the lowest pressure was divided by that at the highest pressure, which was the total settlement in each load cycle. Since these rebound percentages were scattering with load cycles, the average values were taken at every five cycles for the clear illustration and presented in the following figures.

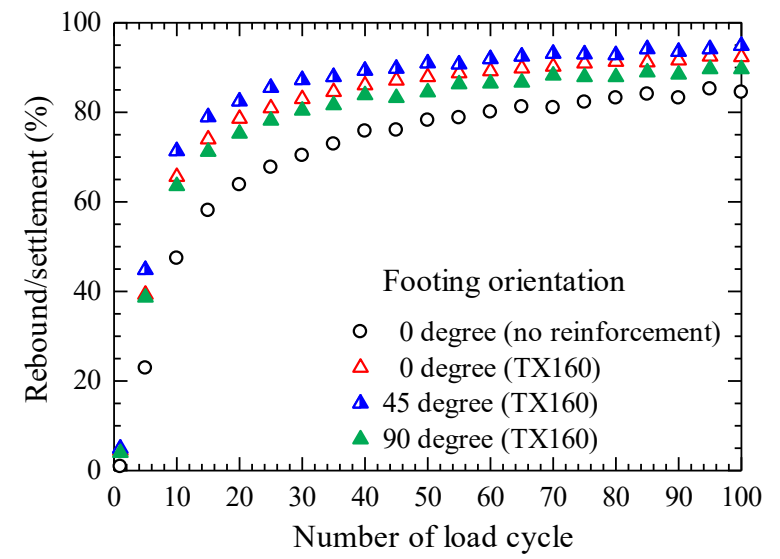

Figure 8. Average rebound in triangular geogridreinforced sand under cyclic loading

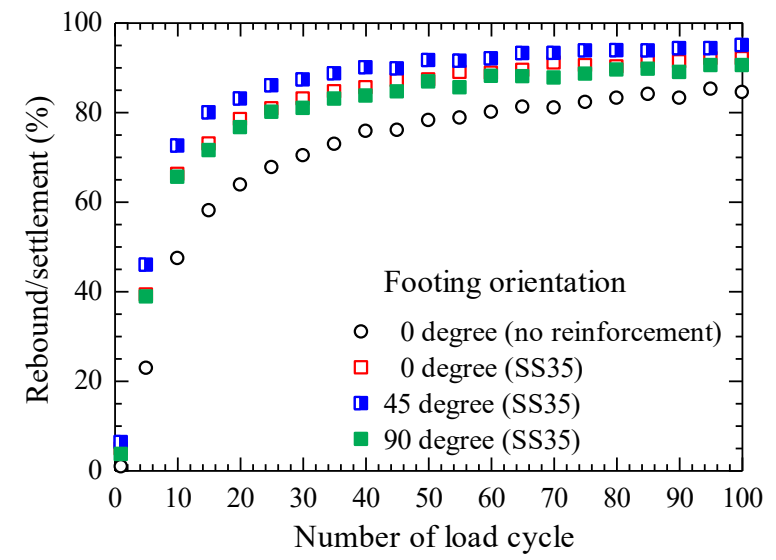

Figure 9. Average rebound in biaxial geogrid-reinforced sand under cyclic loading

As shown in the figures 8 and 9 , it was noticed that there was no obvious difference in rebound percentage with rectangular footing orientations for both reinforcement types. In addition, both types of reinforcement showed above $80 \%$ rebound after $30^{\text {th }}$ load cycle. Then, these rebound values slowly increased to $90-95 \%$ with load cycles. Regarding the rebound behavior, the performances were similar for both types of geogrid, though biaxial geogrid has higher tensile stiffness than that of triangular geogrid. Therefore, it is realized that the influence of geogrid stiffness is negligible on the behavior of rebound under given test conditions.

When rebound values were compared with those of no reinforcement, the amounts of rebound for geogrid- reinforced sand were slightly larger than those of no reinforced sand until $50-60$ load cycles. Then, rebounds in no reinforced sand became larger and were approaching to those in geogrid-reinforced sand. Qian et al. ${ }^{12)}$ conducted a series of cyclic plate loading test and determined the resilient modulus of subgrade based on the rebound deformation of the plate. They reported this modulus values first increased, then decreased and reached a stable value after certain number of loading. Also, this stable condition in turn depended on the load amplitude, which implied more load cycles would be required for the higher load amplitude. Because the percent rebound values were approaching to stable value with increasing load cycles in the current study, it can be regarded that 100 load cycles was enough for the given $100 \mathrm{kPa}$ maximum load amplitude. Almost same rebound percentages for both reinforced and unreinforced cases suggested that the corresponding resilient moduli might also be similar, although these moduli were not calculated in this study. Wayne et al. ${ }^{13)}$ performed a series of the repeated load triaxial test, and their results showed resilient moduli were similar for both geogridstabilized and unbound (unreinforced) specimens though permanent deformations were dramatically different. Hence, this current study is in good agreement with the results reported by Wayne et al. ${ }^{13)}$.

\subsection{Bearing capacity behavior after cyclic loading}

Monotonic loading tests were carried out as soon as cyclic loading tests were completed. Additionally, three monotonic loading tests with 0 -degree footing orientation were performed for no reinforcement, triangular geogrid reinforcement and biaxial geogrid reinforcement. For no reinforcement case, the load - settlement curves from the first cycle of cyclic loading test and monotonic loading test are presented in Figure 10.

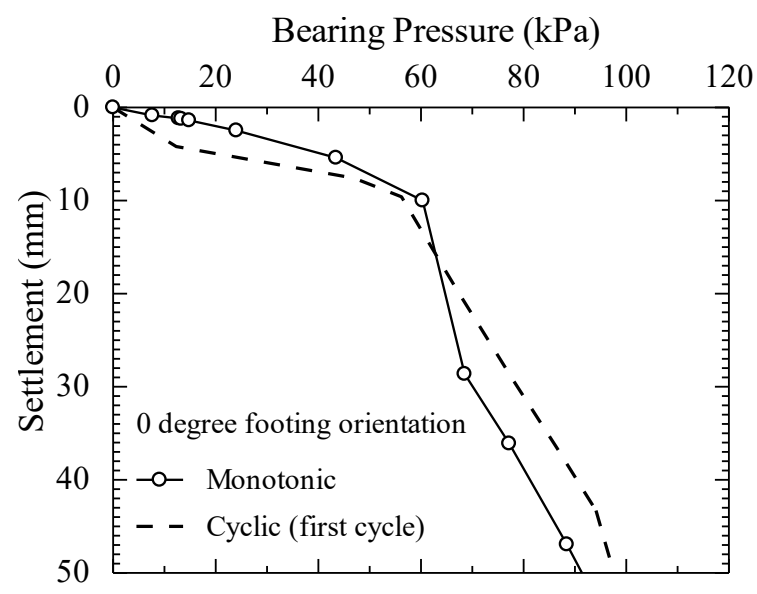

Figure 10. Load-settlement curves of no reinforcement

As shown in Figure 10, load - settlement curves follow almost the same trend to each other, regardless of loading rate. From this figure, the estimated ultimate bearing capacities were $60.32 \mathrm{kPa}$ from monotonic test, and 56.2 
$\mathrm{kPa}$ from the first cycle of cyclic loading test. Thus, the unreinforced sand reached to the failure state during the first cycle of cyclic loading test, in which maximum pressure was $100 \mathrm{kPa}$. It was noticed that the difference in bearing capacity was insignificant between two cases. Since model ground was prepared by using dry sand, there was no possibility of developing excess pore pressure under the given load condition. As a result, the influence of loading rate was negligible on the bearing capacity behavior of unreinforced sand.

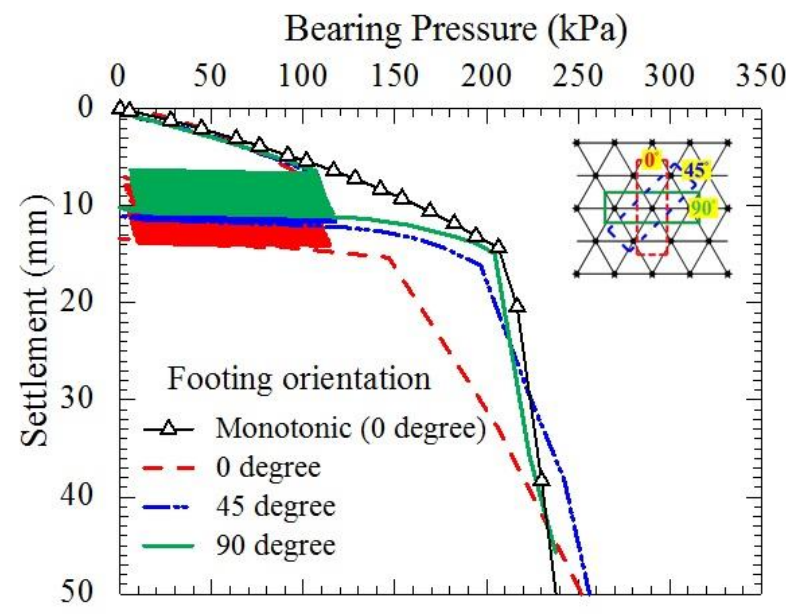

Figure 11. Load-settlement curves of triangular geogrid reinforcement

The behavior of load - settlement curves of triangular geogrid reinforced sand is shown in Figure 11. In the case of monotonic loading test, the curve abruptly changed after $200 \mathrm{kPa}$ pressure. Similarly, the curves of 45 and 90 degree footing orientations followed the same trend of monotonic loading test. On the other hand, this abrupt change was noticed at about $150 \mathrm{kPa}$ for 0 -degree footing orientation. Since the interlocking effect is one of the reinforcement mechanisms ${ }^{11)}{ }^{14)}$, its contribution will influence on the load - settlement behavior and bearing capacity of geogrid-reinforced soil. Hence, the lower lateral confinement with respect to 0 -degree footing orientation, which has been described in the preceding section, would result in poor performance during cyclic loading and subsequent monotonic loading. However, this behavior was not observed in the load - settlement curve of pure monotonic loading test with 0 -degree footing orientation. This was because, during cyclic loading, soil structure might have been deteriorated due to less lateral confinement effect in 0-degree footing orientation. Consequently, the stress concentration would be higher ${ }^{15)}$, and might result in lower bearing pressure in subsequent monotonic loading test. On the other hand, a stable soil structure would contribute enough interlocking effect under pure monotonic loading with 0degree footing orientation.

The ultimate bearing capacities were taken at the point where load - settlement curve changed sharply. The values were $146.71 \mathrm{kPa}, 196.8 \mathrm{kPa}$ and $204.47 \mathrm{kPa}$ for 0 ,
45 and 90 footing orientations respectively. For the pure monotonic loading, the estimated ultimate bearing capacity was $206.51 \mathrm{kPa}$. Thus, except 0 degree footing orientation under cyclic loading, the effect of cyclic loading is insignificant on the ultimate bearing capacity of triangular geogrid-reinforced sand if the geogrid structure is able to maintain enough confinement during cyclic loading.

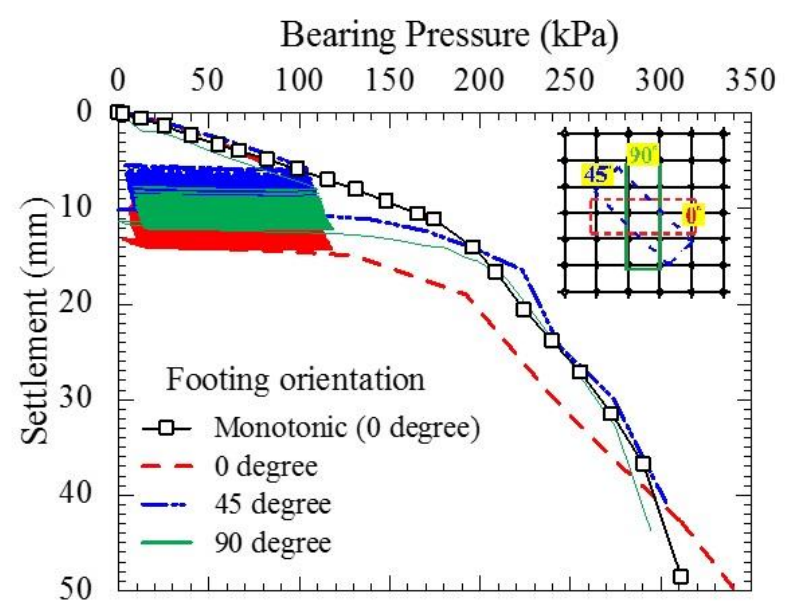

Figure 12. Load-settlement curves of biaxial geogrid reinforcement

Load - settlement curves of biaxial-geogrid reinforced sand are presented in Figure 12. The curves of subsequent monotonic loading tests follow that of pure monotonic loading test, except 0 -degree footing orientation case. This difference in behavior has been discussed in the previous paragraph. Regardless of geogrid type, it was realized that the deterioration of soil particle during cyclic loading was closely related to the degree of lateral confinement of geogrid, and resulted in the behavior of bearing resistance under subsequent monotonic loading. Not like in case of triangular geogrid reinforcement, the curves of biaxial geogrid reinforcement deflected at a slower rate with increasing bearing pressure. This would be due to the contribution from the high tensile stiffness of biaxial geogrid. When a geogrid is deformed under loading, tension membrane effect will develop, and this effect in turn results in an improved vertical stress distribution ${ }^{11)}$. This tension membrane effect will be higher if a stiffer geogrid is used in the reinforced soil mass. Hence, the slow rate of deformations were observed at high bearing pressure in the stiff biaxial geogrid reinforcement.

Since there were no obvious changes in load settlement curves of biaxial geogrid reinforcement, the ultimate bearing capacities were estimated by using tangent intersection technique ${ }^{2}$. These values from the subsequent monotonic loading tests were $193.31 \mathrm{kPa}$, $215.64 \mathrm{kPa}$ and $212.39 \mathrm{kPa}$ for 0,45 and 90-degree footing orientations respectively. For pure monotonic loading, the estimated bearing capacity was $238.35 \mathrm{kPa}$, which was apparently higher than those from the 
subsequent monotonic loading tests. Because tangent intersection technique was used to estimate the ultimate bearing capacity, the values would be slightly varied depending on the tangent point taken at the end of load settlement curve. Though these values were somewhat different, they were close to $200 \mathrm{kPa}$ bearing pressure, near which a small deflection can be seen in load settlement curve of 0 -degree footing orientation in the subsequent monotonic loading test. Hence, the estimated values could be regarded as the reliable ones. Compared to triangular geogrid reinforcement, it was noticed that the ultimate bearing capacity values were more stable in biaxial geogrid reinforcement, especially in case of 0 degree footing orientation. This benefit was due to the high tensile stiffness of biaxial geogrid. Thus, it was realized that the adverse effect of soil particle deterioration during cyclic loading will be less on the bearing capacity behavior of the geogrid-reinforced sand, if the geogrid is stiff enough.

\section{Conclusions}

Cyclic and monotonic loading tests were performed in a large container by using Nikko silica sand No.5, and a slender rectangular footing together with two geogrid types. Considering the footing orientations with respect to geogrid layout, the directional confinement effect of geogrid was investigated on the permanent deformation behavior, rebound characteristics and the ultimate bearing capacity of the geogrid-reinforced sand. From the test results, some conclusions were made as follows:

$>$ Different behavior of permanent deformation ( $\mathrm{s} / \mathrm{B}$ ratio) under cyclic loading was observed for the given geogrid type, depending on its lateral confinement with respect to footing orientations.

$>$ The directional confinement effect of a geogrid varied with the configuration of rib structures, rib thickness and the angle formed between ribs to the lateral direction of rectangular footing. Regarding soil particle size, this influence can be varied.

$>$ Test results implied that more deterioration of soil structure would occur in the lower confinement condition (0 degree footing orientation).

$>$ Under the cyclic loading of $100 \mathrm{kPa}$ maximum pressure, the permanent deformation were reduced above $80 \%$ after 100 cycles of loading in both geogrid-reinforced cases. It means that the influence of geogrid stiffness on permanent deformation is negligible for the given condition.

$>$ With respect to footing orientations, the deviations of $\mathrm{s} / \mathrm{B}$ ratios were larger in biaxial geogrid-reinforced sand than those in triangular geogrid-reinforced sand. Therefore, more uniform directional confinement was achieved with triangular geogrid reinforcement.

$>$ In all cases of cyclic loading tests, the increasing tendencies of $\mathrm{s} / \mathrm{B}$ ratio were observed with the increased number of load cycles. Hence, the directional confinement effect of geogrid will be more pronounced in long term performance of geogrid-reinforced soil.

$>$ The percent rebounds under cyclic loading were similar in both unreinforced sand and geogridreinforced sand. Thus, the reinforcement effect is insignificant on the rebound behavior. This is good in agreement with the reported data from previous studies.

$>$ The ultimate bearing capacity under the subsequent monotonic loading obviously decreased when soil structure had already been deteriorated during cyclic loading. This deterioration was closely related to the directional confinement effect of geogrid. However, this effect on the bearing capacity was negligible if the geogrid could maintain enough confinement during cyclic loading.

$>$ If the geogrid has high stiffness (e.g. SS35), the directional confinement effect became less on the ultimate bearing capacity behavior in the subsequent monotonic loading.

$>$ From the current test results, it was known that the inclusion of geogrid reinforcement could effectively reduce the development of permanent deformation under cyclic loading, and could beneficially improve the ultimate bearing capacity.

\section{Acknowledgements}

This study was collaborated with NIPPO CORPORATION and MITSUI CHEMICALS INDUSTRIAL PRODUCTS LTD. Their supports are highly appreciated.

\section{References}

1) T. Yetimoglu, J. T. H. Wu and A. Saglamer, "Bearing Capacity of Rectangular Footings on Geogrid-Reinforced Sand," Journal of Geotechnical Engineering, ASCE, vol. 120, no. 12, pp. 2083-2099, December 1994.

2) M. T. Adams and J. G. Collin, "Large model spread footing load test on geosynthetic reinforced soil foundations," Journal of geotechnical and geoenvironmental engineering,ASCE, pp. 66-72, 1997.

3) A.-F. Murad, Q. Chen and R. Sharma, "An experimental evaluation of behavior of footings on geosynthetic-reinforced sand," Soils and Foundations, The Japanese Geotechnical Society, vol. 53, no. 2, pp. 335-348, 2013.

4) A. K. Ashmawy and P. L. Bourdeau, "Geosyntheticreinforced soils under repeated loading: a review and comparative design study," GEOSYNTHETICS INTERNATIONAL, vol. 2, no. 4, pp. 643-668, 1995.

5) E. C. Shin and B. M. Das, "Dynamic behavior of geogrid-reinforced sand," KSCE Journal of Civil 
Engineering, vol. 3, no. 4, pp. 379-386, December 1999.

6) J.-P. Bardet, Experimental Soil Mechanics, Upper Saddle River, New Jersey: Prentice-Hall Inc., 1997.

7) V. Murthy, Principles of soil mechanics and foundation engineering, Fifth Revised Edition, New Delhi: UBS Publisher's Distributors Pvt. Ltd., 2003.

8) H. A. Alawaji, "Settlement and bearing capacity of geogrid-reinforced sand over collapsible soil," Geotextiles and Geomembranes, vol. 19, pp. 75-88, 2001.

9) M. A. Gabr and J. H. Hart, "Elastic Modulus of Geogrid-Reinforced Sand Using Plate Load Tests," Geotechnical Testing Journal, GTJODJ, Vol. 23, No.2, pp. 245-245, 2000.

10) B. M. Das, SHALLOW FOUNDATIONS, Second Edition, Bearing Capacity and Settlement, 6000 Broken Sound Parkway NW, Suite 300, Boca Raton: CRC Press, Taylor \& Francis Group, 2009.

11) R. P. Anderson, "Geogrid Separation," in Proceedings of International Conference on New Developments in Geoenvironmental and Geotechnical Engineering, Incheon, Republic of Korea, 2006.
12) Y. Qian, J. Han, S. K. Pokharel and R. L. Parsons, "Determination of resilient modulus of subgrade using cyclic plate loading tests," in Geo-Frontiers Congress 2011, Dallas, Texas, United States, 2011.

13) M. H. Wayne, J. Kwon and R. Boudreau, "Resilient modulus, repeated load permanent deformation and plate load testing of a mechanically stabilized crushed miscellaneous base material," in 90th Annual Meeting, paper number 11-2029, Washington, D.C., 2011.

14) Stephen Archer, P.E., "Subgrade Improvement for Paved and Unpaved Surfaces Using Geogrids," CE News Professional Development Hours, 2008.

15) X. Sun, J. Han, J. Kwon, R. L. Parsons and M. H. Wayne, "Radial stresses and resilient deformations of geogrid-stablized unpaved roads under cyclic plate loading tests," Geotextiles and Geomembranes, vol. 43, no. 5, pp. 440-449, 102015.

\section{繰返し載荷と単調載荷による補強砂地盤の変形挙動と支持力特性に及ぼす}

$$
\text { ジオグリッド拘束効果の方向性の影響 }
$$

\section{Aung Aung Soe $\cdot$ 桑野 二郎・橘 伸也・Ilyas AKRAM}

\footnotetext{
ジオグリッド補強砂地盤の变形挙動と支持力特性を実験により検討した． $100 \mathrm{~cm} \times 100 \mathrm{~cm} \times$ $80 \mathrm{~cm}$ 槽内に作製した模型砂地盤に繰返し載荷および単調載荷試験を実施した．砂地盤には 四角形目合いの二軸ジオグリッドあるいは三角形目合いの三軸ジオグリッドを一層敷設し，載 荷には長方形基礎を用いた。長方形基礎の設置方向を変え，ジオグリッドの拘束効果の方向性 を調べた，残留変形や極限支持力において方向性の影響は顕著であった。しかし，硬いジオグ リッドが使用されると，極限支持力の方向依存性は小さくなった．いずれの場合も，ジオグリ ッドで地盤が補強されると，残留変形や極限支持力について顕著な改善が見られた。
}

キーワード : 補強砂，繰返し載荷，残留変形，支持力 